Gynecol. obstet. Invest. 1983;16:I-V

\title{
Contents, Vol. 16, 1983
}

\section{No. 1 Original Paper}

Experience of Delivery in Women with and without Antenatal Fear of Childbirth

Areskog, B.; Uddenberg, N.; Kjessler, B 1

Circulating Levels of Placental Protein 5 in Normal and Abnormal Pregnancies

Takayama, M.; Soma, H.; Saito, T.; Isaka, K.; Kashiwagi, H.; Ogawa, T.; Suzuki, Y.;

Sayama, S 13

Changes in the Diurnal Rhythms of Plasma Cortisol in Women during the Third Trimester

of Pregnancy

Challis, J.R.G.; Patrick, J.E 27

Relation between Diurnal Changes in Peripheral Plasma Progesterone, Cortisol, and Estriol in Normal Women at 30-31, 34-35, and 38-39 Weeks of Gestation

Challis, J.R.G.; Sprague, C; Patrick, J.E 33

Absorbable Polyglactin Mesh for Retropubic Sling Operations in Female Urinary Stress

Incontinence

Fianu, S.; Söderberg, G 45

Determination of Long-Chain Nonesterified Fatty Acids in Sera of Young Women in Dif

ferent Phases of the Menstrual Cycle. Application of a New Gas Chromatographic

Microliter Method

Hòckel, M.; Holzer, A.; Brockerhoff, P.; Rathgen, G.H 51

Current Investigation

Plasma Somatostatin and Growth Hormone in the Human Fetus and Its Mother at Delivery

Furuhashi, N.; Takahashi, T.; Fukaya, T.; Kono, H.; Shinkawa, O.; Tachibana, Y.;

Wada, Y.; Suzuki, M 59

Book Review 63

Announcements 64

No. 2 Original Paper

Scanning Electron Microscopy of Human Fallopian Tube in Ectopic Pregnancy

Samberg, I.; Degani, S.; Zilberman, A.; Eibschitz, I.; Nir, L; Scharf, M 65

Menstrual-Cycle-Dependent and -Independent Features of the Human Fallopian Tube Fimbrial Epithelium: An Ultrastructural and Cytochemical Study

Lindenbaum, E.S.; Peretz, B.A.; Beach, D 76

Diabetes-Associated Endometrial Disruption in the Ketonuric, Diabetic Chinese Hamster

Garris, D.R.; Smith, C 86

Dopaminergic Regulation of Prolactin Secretion in the Hyperprolactinemic Syndrome Ayalon, D.; Eckstein, N.; Avidan, S.; Eshel, A.; L’Hermite, M.; Caufriez, A.; Spitz, I.; Zylber-Haran, E $\quad 97$

Severe Acquired Antithrombin III Deficiency in Relation to Hepatic and Renal Insufficiency and Intrauterine Fetal Death in Late Pregnancy

Hellgren, M.; Hägnevik, K.; Robbe, H.; Bjòrk, O.; Blombäck, M.; Eklund, J 


\section{Contents}

Cord Serum Growth Hormone in the Human Fetus. Sex Difference and a Negative Correlation with Birth Weight

Furuhashi, N.; Fukaya, T.; Kono, H.; Shinkawa, O.; Tachibana, Y.; Takahashi, T.;

Wada, Y.; Tanaka, M 119

Book Reviews 125

No. 3 Original Paper

A Clinicopathological Study of IUD Users with Special Reference to Endometrial Patterns and Endometritis

Bogaert, L.-J. van 129

Isolation and Characteristics of a Macrophage Population of Human Uterine Mucosa

Laguens, R.M.; Laguens, R.P 136

Relationship between the Maturation Index and Lactate Dehydrogenase Activity in Human Vaginal Epithelium

Punnonen, R.; Lukola, A.; Näse, M.; Söderström, K.-0 142

Effects of Short-Term Treatment with Gonadotropin-Releasing Hormone (GnRH) or Ethinyl Estradiol on the Pituitary Responsiveness to GnRH

Rozenman, D.; Ayalon, D.; Eckstein, N.; Eshel, A.; Lancet, M 147

An Evaluation of Early Pregnancy HCG Determination as a Prognostic Tool for Fetal

Outcome

Bremme, K.; Eneroth, P.; Nord, E 160

Estimation of the Uteroplacental Perfusion by Use of 113mIn-Transferrin and an Iterative

Regression Method

Leodolter, S.; Philipp, K 172

Oxytocin Determination by Radioimmunoassay

Vankrieken, L.; Godart, A.; Thomas, K 180

Book Reviews 186

No. 4 Original Paper

Estrogen- and Gestagen-Receptors in Ovarian Carcinoma

Spona, J.; Gitsch, E.; Salzer, H.; Karrer, K 189

Dermatan Sulphate and Mucin Glycopeptides from the Human Uterine Cervix

Uldbjerg, N.; Carlstedt, I.; Ekman, G.; Malmström, A.; Ulmsten, U.; Wingerup, L. . . 199

Peritoneal Fluid Volume, 17Beta-Estradiol and Progesterone Concentrations in Women

with Endometriosis and/or Luteinized Unruptured Follicle Syndrome

Donnez, J.; Langerock, S.; Thomas, K 210

Nausea and Vomiting in Pregnancy - A Contribution to Its Epidemiology

Järnfelt-Samsioe, A.; Samsioe, G.; Velinder, G.-M 221

Antithrombin III Levels in Normotensive and Hypertensive Pregnancy

Weenink, G.H.; Bonn, J.J.J.; Ten Cate, J.W.; Treffers, P.E 230

2,3-Diphosphoglycerate Concentration in the Red Blood Cells of Anaemic Pregnant Women in Various Periods of Pregnancy

Krasomski, G.; Zachara, B.; Krajewski, J 243

Book Reviews 250

Contents

$\mathrm{V}$

No. 5 Original Paper 
Serum Levels of Pregnancy-Specific ßi-Glycoprotein (SPi) in Women with Pregnancies at Risk

Tamsen, L.; Axelsson, O.; Johansson, S.G.0 253

Immunological and Microbiological Studies of Midtrimester Amniotic Fluid

Davis, L.E.; McLaren, L.C.; Stewart, J.A.; James, C.G.; Levine, M.D.; Skipper, B.J. . 261

Human ACTH, ß-Lipotropin and ß-Endorphin Levels in Maternal Plasma at Delivery

Furuhashi, N.; Takahashi, T.; Fukaya, T.; Fukaya, H.; Shinkawa, O.; Tachibana, Y.;

Suzuki, M 269

Acute Effect of Dihydralazine on Uteroplacental Blood Flow in Hypertension during

Pregnancy

Lunell, N.O.; Lewander, R.; Nylund, L.; Sarby, B.; Thornström, S 274

Histocompatibility Antigens, Mixed Lymphocyte Reactivity and Severe Preeclampsia in

Israel

Persitz, E.; Oksenberg, J.; Amar, A.; Margalioth, E.J.; Cohen, O.; Brautbar, C 283

Increased Postpartum Collagenolytic Activity in Cervical Connective Tissue from Women

Treated with Prostaglandin E2

Ekman, G.; Uldbjerg, N.; Malmström, A.; Ulmsten, U 292

Prolactin Response to the Dopamine Antagonists Sulpiride and Domperidone. Further Evidence

for Pituitary Dopamine Deficiency in Hyperprolactinemic Disorders of Different

Etiology

Ferrari, C; Scarduelli, C; Rampini, P.; Brambilla, G.; Benco, R.; Pistolesi, E.; Paracchi, A.; Mattei, A.; Boghen, M.; Crosignani, P.G 299

Estradiol Receptors in the Urethra and the Bladder of the Female Rabbit

Urner, F.; Weil, A.; Herrmann, W.L 307

Book Reviews 314

No. 6 Original Paper

Estimation of Fetal Maturity by Amniotic Fluid Cytology, Creatinine, Lecithin/Sphingomy-

elin Ratio and Phosphatidylglycerol

Tydén, O.; Eriksson, U.; Ågren, H.; Berne, C

Immunocompetent Cells in Uterine Cervical Lesions of Human Papillomavirus Origin

Syrjänen, K.J 327

Characterization and Comparison of the Contractile Proteins from Human Gravid and Non-

Gravid Myometrium

Cavaillé, F.; Leger, J.J

Comparison of the Effects of Nicardipine and Nifedipine on Isolated Human Myome

trium

Maigaard, S.; Forman, A.; Andersson, K.-E.; Ulmsten, U 354

Book Reviews

367

Announcement

370

Author Index $\quad 371$

Subject Index $\quad 373$ 